\title{
A densidade conflitiva da república nos Discorsi de Maquiavel
}

Republican conflictual density in Machiavellis Discorsi

Neste texto, a atenção estará voltada para o Maquiavel republicano, especificamente para os Discursos sobre a primeira década de Tito Lívio. A análise será dedicada a alguns pontos do texto de Maquiavel que, se articulados, dão a ele uma exclusividade no pensamento político ${ }^{1}$. Tais pontos são o (i) conflito de interesses, que, quando devidamente mediado por instituições, em uma república, a conduz para a (ii) liberdade, a (iii) grandeza e a (iv) expansão. Pretende-se ressaltar a densidade conflitiva que Maquiavel dá à república, não só do ponto de vista descritivo, mas também do normativo, conferindo ao conflito uma positividade que, se não é exclusiva, é bastante distintiva na teoria política. Mas Os Discursos foram escritos entre 1513 e $1519^{2}$ e neles Maquiavel não utiliza os termos conflito nem interesse.

No período em que Maquiavel escreve, interesse não era um termo utilizado no vocabulário político. A ideia de interesse aparece em Maquiavel, mas não com esse nome (Hirschman, 1978, p. 45). São utilizados humores, paixões, apetites. Quanto ao conflito, os termos utilizados são tumultos, desunião, dissensão, oposição e inimizade. Thierry Ménissier, ao buscar definir

\footnotetext{
É professora do Departamento de Ciência Política da Universidade Federal do Rio de Janeiro (Rio de Janeiro, RJ, Brasil).E-mail: mazabreu@uol.com.br.

Agradeço os comentários dos pareceristas anônimos da Revista Brasileira de Ciência Política, que contribuíram e muito para o aprimoramento do texto.

2 A data em que Maquiavel teria escrito os Discursos já foi assunto de controvérsia acadêmica. Estou me baseando aqui no artigo de Felix Gilbert (1953), em que utiliza diversos fatos narrados na obra pra justificar essas datas.
} 
"humor", na obra do autor, afirma que esse designa "não tanto as paixões individuais quanto as aspirações coletivas dos grupos sociais constituídos" (Ménissier, 2012, p. 32). Ao mesmo tempo, o termo permite a Maquiavel "estabelecer que a crise faz parte da vida política normal de qualquer regime" (Ménissier, 2012, p. 33), assim como os humores antagônicos fazem parte da vida dos corpos humanos, de onde vem uma origem hipocrática do termo. No entanto, neste texto, será afastado o componente passional e individual que o termo humor guarda consigo, para destacar a dimensão conflitiva e pública de sua manifestação. Por isso, ele será assumido como interesse, para que possa ser exposto o debate sobre o papel atribuído ao conflito de interesses nos Discursos, assumindo aqui conflito de interesses como aquela incompatibilidade existente entre posições sociais ou políticas manifestadas publicamente (Bergström, 1970).

Para os objetivos deste texto, portanto, o que importa são as manifestações objetivas que os grupos antagônicos realizam. Para isso, será em primeiro lugar colocado em foco o conflito, passando em seguida para o papel que o povo tem na república conflitiva maquiaveliana. Então, será analisada a relação que o conflito assume com as ideias de grandeza e expansão nos Discursos, para então esta última ser relacionada com interesse e liberdade. Por fim, procura-se caracterizar o conflito de interesses presente no texto de Maquiavel.

Atualmente, não há dúvidas de que Maquiavel seja um autor republicano (Hulliung, 1983, p. 234; Viroli, 1998, p. 115). No Brasil, esse reconhecimento foi consolidado com o livro Maquiavel republicano, de Newton Bignotto, publicado em 1991. Também entre o debate especializado sobre Maquiavel, é praticamente consenso que se trata de um autor que, em sua obra, principalmente a republicana, dá ao conflito um caráter positivo (Bonadeo, 1973, p. 39; Pocock, 2003, p. 196; Skinner, 1999, p. 306; Mansfield, 2001, p. 51; Viroli, 1998, p. 126; Bignotto, 1991, p. 95; McCormick, 2011). O que varia é a interpretação sobre o seu alcance. Como argumentos em direção à relativização desse caráter positivo, comumente são utilizados outros pontos importantes na obra de Maquiavel, como a valorização das instituições como mecanismo de canalização desses conflitos, a defesa feita por nosso autor do projeto expansionista romano, ou até mesmo outros textos seus, em particular a História de Florença.

Em favor da afirmação sem restrições do mesmo caráter positivo, o principal argumento são as observações feitas por Maquiavel em relação 
à integração do povo na comunidade política, as quais, combinadas com a ideia positiva de conflito, poderia caracterizar o autor como um democrata bastante radical até mesmo para os referenciais atuais; nesse caso, sua teoria representaria um avanço em relação a muitas teorias contemporâneas de democracia (McCormick, 2011). O objetivo deste texto é justamente o de qualificar e calibrar o conflito de interesses de que trata o autor florentino para tornar possíveis e adequadas eventuais apropriações de sua obra.

\section{O conflito}

Ao analisar os Discursos, se nosso foco é o conflito de interesses, há um capítulo que devemos analisar antes de qualquer outro: o quarto do Livro I. Nesse capítulo, encontramos o seguinte título: "A desunião entre o povo e o Senado foi a causa da grandeza e da liberdade da república romana" ("Che la disunione della Plebe e del Senato romano fece libera e potente quella republica”). Sobre a relação entre povo e Senado na república romana, Maquiavel observa:

Direi que quem condena os tumultos entre os nobres e a plebe parece censurar as coisas que foram a causa primeira da liberdade de Roma e considerar mais as assuadas e a grita que de tais tumultos nasciam do que os bons efeitos que eles geravam; e não consideram que em toda república há dois humores diferentes, o do povo, e o dos grandes, e que todas as leis que se fazem em favor da liberdade nascem da desunião deles, como facilmente se pode ver que ocorreu em Roma (Maquiavel, 2007a, p. 21-22)3.

Confirmando o já apontado, Maquiavel não utiliza o termo interesse, mas "humores" (umori). No entanto, como já discorrido na introdução deste texto, falaremos de interesses, pois, embora a ideia de "humor" possa ter uma conotação subjetiva, Maquiavel a utiliza como modos de manifestação em público de uma posição adotada quanto aos meios e fins a serem utilizados naquele cenário político. Como o autor deixa bem claro: o povo quer apenas não ser oprimido, e os ricos querem oprimir. Bom, essa observação já

No original:"Ma vegnamo agli altri particulari di quella città. lo dico che coloro che dannono i tumulti intra i Nobili e la Plebe mi pare che biasimino quelle cose che furono prima causa del tenere libera Roma, e che considerino più aromori e alle grida che di tali tumulti nascevano, che a'buoni effeti che quelli partorivano; e che e' non considerino come e'sono in ogni republica due umori diversi, quello del popolo e quello de' grandi; e come tutte le leggi che si fanno in favore della liberta, nascano dalla disunione loro, como facilmente se può vedere essere seguinto in Roma" (Machiavelli, 2000, p. 71). 
evidencia também que esses dois humores ou, nos nossos termos, interesses, são conflitivos. Uns estão interessados em oprimir, outros em não ser oprimidos. Aí está presente a incompatibilidade suficiente para caracterizar o conflito. Não é possível que os dois interesses sejam atendidos. Ou um ou outro prevalecerá. Admitido o conflito de interesses presente no texto de Maquiavel, vejamos o tratamento que lhe é dado.

$\mathrm{Na}$ passagem citada, o conflito é uma ideia central e, mais do que isso, positiva, para a comunidade política, pois assegura a conservação de sua liberdade. Essa conservação é possibilitada pelas leis que, por sua vez, emergem do mesmo conflito. Tal valorização do conflito foi e vem sendo bastante destacada pelos comentadores (ver Mansfield, 2001; Pocock, 2003; Bignotto, 1991; McCormick, 2001, 2003, 2011; Hulliung, 1983), variando conforme o sentido que cada um pretende dar para sua própria interpretação. Esse sentido normalmente está relacionado com outro aspecto, que é a necessária inclusão do povo (e de seus interesses) no interior da comunidade política para que se mantenha a liberdade dessa mesma comunidade. Aliás, podemos dizer que a relação de implicação é no sentido contrário. É necessário enfrentar os conflitos existentes na comunidade política para que o povo seja incluído nessa mesma comunidade. Com isso, temos que a admissão do conflito como algo positivo e a inclusão do povo na comunidade política são ideias relacionadas na obra de Maquiavel.

A valorização do conflito é o fundamento teórico e até mesmo "sociológico" para a defesa do governo misto proposto por Maquiavel sem muitas explicações logo no capítulo 2 do Livro I. Se o governo misto é a mistura das diversas formas de governo (monarquia, aristocracia e democracia), por meio das instituições do Consulado, do Senado e do povo, essa forma é a que admite, em seu interior, que os interesses opostos existentes na comunidade política possam se expressar e se tornar públicos.

Além da defesa do governo misto, Maquiavel defende outras instituições que possibilitem a manifestação dos humores dos cidadãos, principalmente do povo em relação aos nobres, como é o caso das denúncias públicas:

se deve notar o que acima dissemos, a respeito da utilidade e da necessidade de as repúblicas, com suas leis, permitirem o desafogo da ira que o povo vota a um cidadão; porque quando não há esses modos ordinários, recorre-se aos extraordinários; e sem dúvidas estes produzem efeitos muito piores que aqueles (Maquiavel, 2007a, p. 34). 
Além de mecanismo de canalização das paixões, as instituições voltadas para as demandas populares servem também de mecanismos de salvaguarda da liberdade, em razão da maior estabilidade que o povo apresenta quando comparado aos nobres:

E sem dúvida, se considerarmos o objetivo dos nobres e dos plebeus [ignobili], veremos naqueles grande desejo de dominar e nestes somente o desejo de não ser dominados e, por conseguinte, maior vontade de viver livres, visto que podem ter menos esperança de usurpar a liberdade do que os grandes; de tal modo que, sendo os populares encarregados da guarda de uma liberdade, é razoável que tenham mais zelo e que, não podendo eles mesmos apoderar-se dela, não permitirão que outros se apoderem (Maquiavel, 2007a, p. 24).

Essa defesa do povo em relação aos nobres como o segmento mais adequado para cuidar da conservação da comunidade política sugere que temos em Maquiavel um defensor da supremacia popular, ou de uma democracia bastante radical. Mas vejamos qual é a extensão dessa proposição ao longo dos Discursos.

\section{Conflito e a participação do povo na comunidade política}

A valorização do conflito e a inclusão do povo no interior da comunidade política fez McCormick ver em Maquiavel um verdadeiro defensor de uma "democracia populista". McCormick apresenta a sua tese em um artigo publicado em 2001 e, depois de outros artigos publicados, estrutura uma democracia maquiaveliana, conforme exposto em seu livro recente, de 2011. Convém expor aqui seus argumentos, pois nos permitem explorar bastante o alcance da teoria de Maquiavel.

Com o propósito de contribuir no debate acerca da accountability das elites na teoria democrática contemporânea, McCormick aponta que Maquiavel apresentou, nos Discursos, mecanismos institucionais de controle das elites. Segundo ele, Maquiavel reduziu seu espaço, ao conferir ao povo o papel de "guardião da liberdade", defendeu a existência de mecanismos de participação popular, ao propor as denúncias públicas, condenando as calúnias, e reconheceu os benefícios da ação coletiva, ao afirmar que o povo, coletivamente, por não querer ser dominado, decide melhor acerca dos rumos da república e distribui melhor os cargos públicos (McCormick, 2011, p. 7). McCormick 
chega a afirmar que o governo misto proposto por Maquiavel é uma mistura de "participação direta e representação popular". Nessa democracia popular, que ele chama de maquiaveliana, a contestação cívica é institucionalizada por meio de instâncias como os Tribunatos da plebe, nos quais os mais ricos não podem participar, e a participação direta do cidadão é possibilitada pelas assembleias populares, que ou excluem totalmente a participação dos nobres, ou tornam sua influência insignificante (McCormick 2011, p. 7). Tais mecanismos seriam, segundo McCormick, instrumentos de canalização de um comportamento "feroz" do povo, reagindo às ameaças constantes de que sua liberdade seja violada pelas elites. Por isso ele fala de um "ferocious populism" sugerido por Maquiavel.

De fato, Maquiavel apresenta defesas da sabedoria e da estabilidade próprias do povo, bem como de diversos atributos deste em relação à capacidade de defender e resguardar a liberdade da república. As passagens citadas por McCormick, algumas delas já reproduzidas aqui, demonstram isso. No entanto, o pensamento de Maquiavel não parece ser tão unívoco assim.

No capítulo 37 do Livro I, quando Maquiavel apresenta os problemas enfrentados com a Lei Agrária em Roma, nosso autor observa que não se pode passar por cima de cada um dos interesses conflitantes de forma abrupta. Isso faria com que os conflitos fossem acirrados de tal modo que as duas partes passariam a utilizar mecanismos que ameaçassem a liberdade da república, e poderiam inclusive ocasionar a tirania. Portanto, na dinâmica do conflito, não há que falar em uma das partes, ainda que esta seja o povo, passar por cima da outra. A existência e convivência das duas partes conflitivas é essencial para a manutenção da liberdade e para a própria conservação da república. Isso é confirmado na seguinte passagem, em que Maquiavel comenta a tirania do Decenvirato romano e a relutância do Senado em realizar algum ato que evitasse essa tirania e pudesse restaurar o seu próprio poder e o dos Tribunatos populares:

nota-se em primeiro lugar que em Roma se incorreu no inconveniente de criar uma tirania pelas mesmas razões por que nasce a maior parte das tiranias nas cidades: pelo demasiado desejo do povo de ser livre e pelo demasiado desejo dos nobres de comandar. E, quando não se acordam na criação de uma lei em favor da liberdade, mas alguma das partes se opõe a favorecer alguém, logo surge a tirania (Maquiavel, 2007a, p. 127). 
Esse acordo entre as partes conflitantes a que se refere Maquiavel na passagem acima deve sempre ser feito de forma pública. Publicidade é uma ideia chave no pensamento republicano do autor e parece ser esse o fio que indica o alcance que pode ter o conflito para que ele seja considerado positivo. Isso porque, para Maquiavel, não é qualquer conflito, ou qualquer disputa entre o povo e os nobres que possa ser considerada positiva na vida de uma república. Os conflitos que não forem devidamente tornados públicos por meio das instituições são conflitos facciosos que, ao contrário de à grandeza, levam à ruína da república:

Se for governada por uma república, não há melhor modo de tornar maus os teus cidadãos e de dividir a tua cidade do que ter a posse de [avere in governo] uma cidade dividida; porque cada parte procurará obter favores, e cada uma delas angariará amigos com vários tipos de corrupção, de modo que disso provirão dois grandes inconvenientes; um é que eles nunca serão teus amigos, visto que os podes bem governar, porque o governo variará com frequência, ora com um humor, ora com outro; o segundo inconveniente é que o favorecimento de partidos mantém necessariamente a tua república dividida (Maquiavel, 2007a, p. 404-405).

Nesse sentido, Newton Bignotto comenta que o papel do Estado, na obra de Maquiavel, é o de se opor, pela força de suas leis, à ação destruidora dos desejos particularistas; e a sociedade justa, por sua vez, é aquela que é "capaz de encontrar uma solução pública para o conflito de seus cidadãos" (Bignotto, 1991, p. 95). Na busca dessa solução pública, há uma latente tensão entre o público e o privado, o comum e o particular. Para que tal solução pública seja alcançada é necessário que os interesses se manifestem não como interesses particulares ou facciosos, mas como aqueles que se pretendem comuns. Nesse aspecto, não importa se são interesses de origem popular ou aristocrática, mas a vocação deles de se tornarem ou não públicos, ou seja, de serem transparentes para informar os mecanismos de solução pública. Com tudo isso, podemos perceber que Maquiavel não defende a oposição de interesses, qualquer que ela seja. Embora tenha tido o mérito de identificar e explorar a origem social dos conflitos existentes na política republicana ${ }^{4}$, e de ter defendido, de forma bastante incisiva, a inclusão do

Afirmo isso baseada na seguinte observação de Alfredo Bonadeo: "Maquiavel atribui valor positivo ao conflito somente sob circunstâncias particulares, como será visto; mas ele foi de fato o primeiro 
povo na comunidade política, não se pode dizer que Maquiavel defenda uma espécie de "supremacia popular" nas decisões públicas. Diversos autores têm destacado isso. Alfredo Bonadeo frisa a necessidade de que as instituições retratem algo além dos simples interesses de cada grupo para que elas sejam estáveis ${ }^{5}$. Skinner apontou o quanto as instituições, na obra de Maquiavel, vão além dos interesses de cada grupo para promover o bem público. As leis, com isso, teriam um poder coercitivo sobre cada grupo, fazendo com que os interesses das facções tenham que se acomodar às proposições legais de interesse público (Skinner, 1999, p. 305-306). Maurizio Viroli, seguindo a linha interpretativa de Skinner, defende que a república de Maquiavel é marcada por um compromisso com o ideal de uma república bem-ordenada, ou seja, aquela que, por meio de instituições que asseguram a cada grupo seu lugar próprio, submete-se ao rule of law. Essa ideia de boa ordem certamente não tem a ver com a ausência de conflitos ou de alguns tumultos no interior da república ${ }^{6}$, mas de um compromisso de cada componente da vida pública com o princípios da vida política e civil (vivere politico; vivere civile) (Viroli, 1998, p. 116).

Esse entendimento se reforça se levarmos em consideração a seguinte passagem, não dos Discursos, mas da História de Florença:

As graves e naturais inimizades que existem entre as pessoas do povo e os nobres, causadas porque estes querem mandar e aqueles não querem obedecer, são os motivos de todos os males que surgem nas cidades, porque desta diversidade de humores nutrem-se todas as outras coisas que perturbam as repúblicas. Foi isso o que manteve Roma desunida; isso, se lícito for igualar pequenas e grandes coisas, manteve Florença dividida; diversos foram os efeitos resultantes numa e noutra cidade,

pensador a se tornar, de forma afiada, consciente das origens políticas e sociais e das implicações da divisão e do conflito no contexto da história romana e florentina" (Bonadeo, 1973, p. 39-40, tradução minha). Esse tema será retomado mais tarde, quando abordarmos o tipo de interesse de que fala Maquiavel.

"Uma vez que leis e instituições de uma cidade dividida por facções representa somente os interesses de homens em particular e fações, essas leis e instituições são inerentemente instáveis, pois elas tendem a variar na medida em que as facções ascendem ou entram em decadência" (Bonadeo, 1973, p. 51, tradução minha).

- Nesse sentido, é exemplar a seguinte passagem de Maquiavel: "E se os tumultos foram razão para a criação dos tribunos, merecem sumos louvores; porque, além de concederem a parte que cabia ao povo na administração, tais tribunos foram constituídos para guardar a liberdade romana, como se mostrará no capítulo seguinte" (Maquiavel, 2007a, p. 23). 
convenha-se, porque as inimizades que no início surgiram em Roma entre o povo e os nobres definiram-se discutindo, e em Florença, combatendo; as de Roma com a lei, as de Florença, com a morte e com o exílio de muitos cidadãos terminaram; as de Roma, sempre a virtude militar aumentaram, as de Florença, de todo apagaram-na; as de Roma, de uma igualdade entre os cidadãos a uma grandíssima desigualdade conduziram, as de Florença, de uma desigualdade a uma assombrosa igualdade reconduziram (Maquiavel, 2007b, p. 136).

Como se vê, o que parece diferenciar o conflito "positivo" do conflito "negativo" no interior das repúblicas é justamente a maneira como está relacionado com as instituições. Além disso, está indicado que, para Maquiavel, a igualdade alcançada não é algo que seja marca da grandeza de uma república, embora a existência de alguma igualdade seja um requisito necessário para a sua constituição. Nesse sentido, veja-se que para Maquiavel a igualdade não é algo a ser obtido com a política, mas algo já existente, que pode ou não ser estimulado e cultivado, como podemos ver na seguinte passagem:

Que se constitua, portanto, uma república onde existe ou se criou uma grande igualdade, e, ao contrário, que se ordene um principado onde haja grande desigualdade, caso contrário se criará algo sem equilíbrio [proporzione] e pouco durável (Maquiavel, 2007a, p. 163).

McCormick (2011) trata da questão da desigualdade social, adotando um vocabulário contemporâneo, não presente em Maquiavel. O autor coloca nas instituições a serem criadas na república uma necessidade de que elas contribuam para a redução das desigualdades com o intuito de responder a demandas democráticas do presente que certamente não estão presentes em Maquiavel. No entanto, ele reivindica a legitimidade de sua interpretação, demonstrando que a interpretação daquela que ele denomina escola de Cambridge, na qual inclui Pocock, Skinner, Pettit e Viroli, afasta o caráter popular da própria república maquiaveliana e também das demandas das democracias contemporâneas. Ele já havia se dedicado a criticar esses autores em artigo anterior seu, de 2003: "Machiavelli against republicanism: On the Cambridge School's Guicciardinian moments". Nesse artigo, o autor, de maneira bastante incisiva, até mesmo raivosa, se 
insurge contra Cambridge e diz que a interpretação desses autores está aquém do alcance antielitista da obra de Maquiavel. McCormick afirma que a teoria de Maquiavel é mais igualitária do que a tradição republicana, na qual Maquiavel está incluído, invocada por tais autores (McCormick, 2003, p. 617). Os argumentos são pontuais para cada comentador, e não se discorrerá sobre eles aqui. A crítica é retomada em seu livro. McCormick parece ter razão ao atribuir a esses autores uma interpretação "moderada" de Maquiavel, na medida em que valoriza demais o papel das instituições em "neutralizar" o conflito. No entanto, acreditamos que McCormick exagera no caráter "popular" que atribui à república maquiaveliana. Vamos desenvolver esse argumento.

Para defender sua república popular maquiaveliana, McCormick questiona a legitimidade de que se coloquem no mesmo plano as diversas obras de Maquiavel. Segundo ele, cada uma delas tem um objetivo retórico específico e, portanto, deve ser analisada em seu contexto. Assim, a História de Florença, dedicada ao Papa Clemente VII (Giulio de Médici) não poderia ser analisada da mesma forma que os Discursos, obra destinada a uma audiência muito mais ampla. De fato, nosso autor florentino dedica seu texto a dois de seus amigos, Buondelmonti e Rucellai, de origem popular. Ocorre que, admitindo que McCormick tenha razão - e Skinner compartilharia desse mesmo entendimento (Skinner, 1999) \, é necessário observar que nos próprios Discursos é possível verificar que Maquiavel é contrário a qualquer tipo de prevalecimento do interesse, ou das paixões, de uma das partes que compõem a estrutura social da república. Qualquer situação em que prevaleçam interesses parciais pode levar à ruína da república, conforme já indicamos em outras passagens. Se levarmos adiante a análise da retórica sugerida por McCormick, veremos que a própria defesa do povo pode ser interpretada nesse registro como um recurso de convencimento a respeito da ideia de que o povo deva estar ainda mais incluído na vida da república, em oposição à ideia dominante de que uma república aristocrática seria o modelo a ser seguido. Essa parece ser a interpretação sugerida por Bignotto, quando afirma que a defesa de Maquiavel é mais antiaristocrática que popular, buscando evitar que seja fundada em Florença uma república de inspiração veneziana, em que o povo estaria excluído (Bignotto, 1991, p. 109).E por que isso? A partir do que se depreende do texto, pelas características da república que Maquiavel pretende ver fundada em Florença: 
Se alguém, portanto, quiser ordenar uma nova república, terá de examinar se quer que ela cresça em domínio e poder, como Roma, ou que permaneça dentro de limites exíguos. No primeiro caso, é necessário ordená-la como Roma e dar lugar da melhor maneira possível a tumultos e a dissensões entre cidadãos [universali]; porque, sem grande número de homens bem armados, nunca república alguma poderá ampliar-se, e, caso se amplie, não poderá manter-se (Maquiavel, 2007a, p. 30).

As alternativas a Roma que Maquiavel tem em vista nessa passagem são Esparta e Veneza, um exemplo antigo e outro contemporâneo à Florença da época. Ambas as repúblicas não tinham como objetivo crescer e expandir-se. Portanto, poderiam preservar seu caráter aristocrático e desenvolver sua vida política sem se preocupar com a inclusão de cidadãos e com sua incorporação a um exército numeroso. No entanto,

Quem quiser que uma cidade forme um grande império, deverá empenhar-se para enchê-la de habitantes; porque, sem essa abundância de homens, nunca conseguirá tornar grande uma cidade (Maquiavel, 2007a, 193).

Essa última passagem nos indica uma outra noção muito importante na obra de Maquiavel como um todo: a de grandeza. No caso dos Discursos, ela está associada, sem dúvida, à expansão militar e territorial da república, para a qual é necessário um exército numeroso, que não poderá ser constituído sem a participação popular, como a passagem acima indica, mas não somente a ela. Vejamos.

\section{Conflito, grandeza e expansão}

A noção de grandeza é bastante forte na obra de Maquiavel, e nos Discursos ela ocupa um lugar central' ${ }^{7}$ É de grandeza que Maquiavel está falando quando elege Roma como exemplo de república. E ela mesma, quando aplicada a Roma, nos leva quase que intuitivamente à ideia de expansão, e esta, por sua vez, ao capítulo 6 do Livro I dos Discursos. A expansão romana, para Maquiavel, somente foi possível por haver, naquela república, um grande número de pessoas compondo o exército, ou seja, foi porque o povo estava integrado ao exército - que por isso se tornou numeroso - que a expansão foi

Ao analisar a obra de Maquiavel, Skinner observa que os Discursos não tratam apenas das repúblicas, mas da grandeza das cidades, enquanto O príncipe cuida dos conselhos ao governante (Skinner, 1988, p. 51). 
possível. Para ter esse exército numeroso, com o povo integrado à política, torna-se necessário enfrentar os conflitos que envolvem os interesses do povo e os demais existentes no interior da república. É isso o que Maquiavel parece querer dizer quando afirma:

Portanto, se queres criar um povo numeroso e armado para poderes criar um grande império, acabarás por fazer de tal maneira que depois não poderás depois manejá-lo a teu modo; e, se o manténs pequeno ou desarmado para poderes manejá-lo, se conquistares domínios não os poderá conservar, ou eles se tornarão tão fracos que serás presa fácil de quem te atacar (Maquiavel, 2007a, p. 30).

Outra opção que não um exército formado por pessoas do povo seria um exército formado por soldados contratados, um exército de mercenários. Mas esses soldados não teriam o patriotismo necessário para formar um exército corajoso e destemido. O patriotismo é um elemento precioso no campo teórico republicano e, na obra de Maquiavel, ocupa um lugar importante mesmo em $O$ príncipe. É ele uma espécie de cimento que faz com que as comunidades políticas se tornem mais coesas e, sejam elas repúblicas ou principados, possam sobreviver às dissensões e durar. Além disso, Maquiavel defende que se crie numa república um treino permanente para a guerra, pois isso tem efeitos positivos não somente para o próprio exército como para a vida civil na república. Nesse sentido, devem-se amenizar os efeitos perniciosos que pode ter um período de paz:

E, refletindo nos possíveis remédios para tanto, chego a dois; um é manter os cidadãos pobres, para que, com riquezas sem virtù, eles não se possam corromper nem aos outros; o outro é ordenar-se de tal modo para a guerra que sempre seja possível entrar em guerra e sempre se tenha necessidade de cidadãos bem reputados, como fizeram os romanos em seus primeiros tempos. Porque, como aquela cidade sempre tinha exércitos fora de suas fronteiras, sempre haveria lugar para a virtù dos homens; e não se podia privar de sua grau aquele que o merecia, dando-o a alguém que não o merecesse: porque, se isso fosse feito alguma vez, por erro ou tentativa, logo advinham tanta desordem e tanto perigo que depressa se voltava à verdadeira via (Maquiavel, 2007a, p. 375).

A virtude militar e a capacidade de expansão, sem dúvida, são aspectos da grandeza romana destacada e valorizada por Maquiavel, mas tal grandeza está associada também ao caráter institucional da república romana, como 
está presente no capítulo 4 do Livro I dos Discursos e também pode ser visto na seguinte passagem:

se nunca houve república que tenha conquistado o que Roma conquistou, é porque nunca se encontrou república que fosse ordenada de tal modo que pudesse conquistar como Roma. Porque foi a virtù dos exércitos que lhe permitiu conquistar o império, e foram o seu modo [lordine] de proceder e o modo como ela própria era constituída, estabelecido pelo seu primeiro legislador, que permitiram conservar o que fora conquistado (Maquiavel, 2007a, p. 181-182).

Como se vê, a grandeza romana, tida por Maquiavel como exemplar, parece apresentar dois aspectos: um expansionista e outro institucional. Há um terceiro, menos explícito, que fica mais claro se pensarmos os Discursos em conjunto com o Príncipe, e que chamaremos aqui de "fenomenológico". Esse terceiro aspecto foi valorizado em sua forma mais acentuada por Hannah Arendt. Ele diz respeito à glória conferida pelos atos políticos, tanto ao ator político como à comunidade política como um todo. Essa valorização está presente no ensaio de Arendt "Que é autoridade?", que faz parte da coletânea Entre o passado e o futuro, mas se encontra de forma mais explícita em suas notas de aula sobre Maquiavel (Arendt, 1965, p. 300), quando coloca a grandeza como critério último do Estado concebido por Maquiavel. Mas essa grandeza, que pode ser entendida como glória, é algo obtido também pelo indivíduo/cidadão:

O principal conceito da ação política é a glória, que é alcançada pela fortuna e pela virtù: a glória para um povo ou um príncipe ou quem quer que esteja envolvido nos negócios mundanos. A glória brilha - doxa [aparência, louvor], aparece, é vista e se faz ver. O príncipe realiza grandes empresas pela glória eterna e a glória presente. A fama é o prolongamento da glória, é a glória tornada durável. A glória brilha por si mesma graças a todas as grandes ações e empreendimentos (Arendt, 1965, p. 300-301).

Essa definição de glória e a valorização da política como aparência ${ }^{8}$ são o grande ponto em comum que Arendt tem com Maquiavel, e a faz ter desse autor tão destoante do seu modo de ver a política uma das interpretações

8 Para uma análise minuciosa sobre a importância da aparência e suas diversas dimensões: visibilidade, observação, juízo, imagem, engano e retórica, ver Adverse (2009). 
mais luminosas. No Maquiavel de Hannah Arendt, glória, fama e grandeza estão relacionadas com os grandes feitos e realizações que entram para a história. Nessa medida, estão relacionados, também, com a capacidade dos atores de deixarem de lado seus interesses pessoais mais mesquinhos e agir em torno de feitos e causas que deixem sua marca no mundo. No entanto, pode-se afirmar que, nessa interpretação, Hannah Arendt não leva em consideração dois pontos: o conflito e a expansão.

Como eles se relacionam? Para responder, temos de levar em consideração a situação política em que se encontra a república antes de cada elaboração institucional. Como já vimos, essa elaboração, no caso exemplar romano, passa pelo enfrentamento dos conflitos existentes no interior da república. A sua existência, ou seja, a manifestação pública de interesses opostos, por si só, já apresenta um ganho para a república, pois cada um dos interesses (ou paixões) em questão freia o seu oposto e, assim, contém seus excessos. Enfim, é da manifestação de cada parte oposta que a outra pode ser freada. Desse conflito entre os segmentos de cidadãos podem surgir instituições voltadas para o bem comum e que incorporam o povo à comunidade política, que por sua vez possibilitam a formação de grandes exércitos e a expansão da república.

Essa última relação fez Mark Hulliung afirmar que o conflito social, para Maquiavel, é funcional não meramente porque possibilita a existência de freios e contrapesos que asseguram a liberdade, mas também porque oferece combustível para a engrenagem da guerra, e para a tendência da república à grandeza (Hulliung, 1983, p. 26). A interpretação de Hulliung é bastante inclinada para um lado "imperialista" de Maquiavel e, logo no começo de seu livro Citizen Machiavelli, chama atenção para esse tema, que o autor julga ter sido esquecido na interpretação contemporânea dada ao autor florentino e que havia sido valorizado por Harrington. Hulliung afasta a importância dada à retórica, criticando toda a linha de interpretação desenvolvida por Pocock e Skinner, e frisa bastante o lado de Maquiavel voltado para a glória e a grandeza não só dos cidadãos mas das comunidades políticas.

Em favor dos argumentos de Hulliung, está a "classificação" feita por Maquiavel entre as repúblicas que querem crescer e as que não o querem, e as primeiras são as que devem conferir ao povo a atribuição de guardião da liberdade: 
E, no fim, quem examinar tudo sutilmente chegará a esta conclusão: ou se pensa numa república que queira fazer um império, como Roma, ou numa à qual baste manter-se. No primeiro caso, é necessário fazer tudo como Roma; no segundo, pode-se imitar Veneza e Esparta (Maquiavel, 2007a, p. 25).

Como se vê nessa passagem, o que diferencia Roma das demais repúblicas é sua vontade de adquirir um império. Se o intuito for somente a conservação, pode-se ter Esparta e Veneza como modelo. No entanto, como sabemos, Maquiavel elege Roma. E, se a expansão era a sua marca, então pareceria possível concluir, junto com Hulliung, que a expansão seja o grande objetivo para Maquiavel.

Pocock (1985) se opõe a essa interpretação de Hulliung em seu artigo "Machiavelli in the liberal cosmos", apontando que a visão de Hulliung de que Maquiavel teria a conquista e a glória como seus únicos objetivos, e de que toda a sua obra deveria ser lida com esse propósito em vista, é bastante extremada e constitui apenas uma parte da teoria maquiaveliana. O que parece dar razão a Pocock é o fato de que a importância atribuída por Maquiavel às instituições não parece ser apenas um acessório da conquista, embora essa relação às vezes esteja presente.

Mikael Hörnquist (2004), embora enfatize o tema da expansão e o aspecto imperial da república proposta por Maquiavel, matiza o tratamento dado a ela por Hulliung, relativizando seus aspectos militares. Em sua análise, aponta diversas passagens (Hörnquist, 2004, p. 74), como feito aqui, em que os arranjos institucionais são também considerados tão importantes quanto um exército bem armado para a expansão. De qualquer forma, ele reforça a interpretação de Hulliung de que a expansão é um objetivo central, inclusive do povo romano (Hörnquist, 2004, p. 72).

Talvez Hulliung esteja certo em colocar a grandeza como o objetivo central de Maquiavel, como Hannah Arendt o fez. Mas as duas interpretações do que seja grandeza na obra de nosso autor talvez não se adequem ao que está presente nos Discursos. Ela nem é somente expansão, como pretendem Hulliung e Hörnqvist, nem é só aparecimento em público e permanência na história, como formula Arendt. Ela é algo mais, como passa a ser verificado.

\section{Interesse, liberdade e expansão}

Curiosamente, na tentativa de definição do que seria a grandeza na obra de Maquiavel, esteve até agora fora do centro de nossas preocupações outro 
tema, bastante caro ao nosso autor e a seus comentadores: a liberdade. E aqui temos de iniciar nossa exposição enunciando que a liberdade, para Maquiavel, é um atributo não somente dos cidadãos mas também das comunidades políticas. Nesse aspecto, as repúblicas são as formas de governo em que as comunidades políticas melhor podem ser livres. Maquiavel chega a qualificar as repúblicas de Esparta e Veneza como livres, o que nos levaria a concluir que liberdade não necessariamente está relacionada com expansão. O que podemos afirmar é que a liberdade pode ser considerada o par oposto de corrupção, pois a ruína de uma república, ou seja, a perda de sua liberdade, se dá quando fontes de corrupção emergem e tomam conta da vida pública. "A liberdade é, portanto, a chave para a compreensão das vitórias de uma cidade, mas também a causa da fraqueza daquelas que não a possuem" (Bignotto, 1991, p. 79). Ao longo dos Discursos, Maquiavel aponta uma série de comportamentos que podem ser considerados fontes de corrupção: (i) a conspiração, que se realiza sempre que um cidadão ou um grupo de cidadãos atenta contra alguma instituição da república, o que acontece principalmente quando há mudança de regime e os que foram prejudicados com a mudança tentam restituir as vantagens anteriores; (ii) as calúnias, que são objeto de um capítulo específico dos Discursos (o oitavo), que consiste na denúncia, privada, sem provas, de alguém por outrem, geralmente motivada por inveja, ódio ou algum motivo faccioso; (iii) formação de lealdades privadas (ex.: poderio militar, aproveitamento de ocupação de funções públicas), daí a necessidade de mandatos temporários, pois a permanência por um longo tempo em funções públicas pode intensificar essas lealdades; e (iv) existência de cidadãos muito mais ricos que outros, na medida em que isso possibilita o suborno de ocupantes de funções públicas e a "compra" dos mais pobres. Em todos esses tipos de fontes de corrupção está presente o prevalecimento dos interesses particulares de um cidadão ou de um grupo deles sobre o interesse público e sobre os mecanismos públicos de manifestação de paixões, como é o caso das calúnias.

Alfredo Bonadeo formula uma definição de corrupção na obra de Maquiavel que, se não é precisa, ao menos nos fornece elementos para estruturar a análise desse tema: "Na Itália, e especialmente em Florença, corrupção correspondia aos maus costumes, vícios, desrespeito às leis, a existência de facções e a ausência de liberdade e, naturalmente, o governo desordenado" (Bonadeo, 1973, p. 9). Os vícios e maus hábitos a que se refere Bonadeo 
certamente não são vícios morais. Sabemos que essa não é a preocupação de Maquiavel. São eles, sim, comportamentos dos cidadãos que se dão tendo em vista unicamente o interesse privado e que atentam contra a ordem e o bem comum. As calúnias são o exemplo mais bem acabado disso. $\mathrm{O}$ desrespeito às leis é uma das causas fundamentais de corrupção, pois, como veremos, as leis são o que possibilita constituir e manter uma comunidade política livre e cumprem papel fundamental nas repúblicas. A existência de facções está relacionada com a corrupção, como vimos, por representar mecanismos de prevalecimento de interesses de grupos e portanto, parciais, em relação aos interesses de toda a comunidade e ao bem comum. A ausência de liberdade está relacionada com as relações de dominação no interior da república. Por sua vez, o governo desordenado é aquele utilizado não para o bem da comunidade, mas no interesse daqueles que ocupam seus cargos ou de grupos favorecidos, o que pode ocorrer não só com os mecanismos de favorecimento diretos deste ou daquele grupo de cidadãos, mas com decisões institucionais equivocadas, que podem sê-lo principalmente quanto ao tempo. Decisões políticas, sejam elas quais forem, devem ser tomadas no tempo certo (Maquiavel, 2007a, p. 349).

De todos esses elementos, detenhamo-nos um pouco mais no desrespeito às leis. Estas, que aqui serão tratadas como sinônimo de instituições, pois no texto de Maquiavel não há distinção entre esses dois termos, têm um papel crucial na constituição e na conservação de uma república. Não é por acaso que nosso autor começa os três livros em que se encontram divididos os Discursos observando a necessidade de instituições adequadas para a vida de uma república. As instituições estão relacionadas tanto com a liberdade como com a grandeza da república. Estas duas últimas constituem aspectos relacionados, em que um é aumentado proporcionalmente de acordo com o outro.

A respeito das instituições, há algo em Maquiavel bastante presente e que marca sua obra: a importância do momento da fundação da república e de sua atualização institucional. A fundação envolve, em primeiro lugar, a escolha de um território e a escolha de uma forma institucional que inaugurará a comunidade política. Embora haja dois tipos de república (Maquiavel, 2007a, p. 12-19), um que recebe de um só homem e de uma só vez toda a legislação (Esparta) e outra que recebe a legislação gradualmente (Roma), o ato de fundação é sempre um ato solitário (Maquiavel, 2007a, p.40-43) e violento. Esse ato deve ser feito não de acordo com os interesses pessoais do 
legislador/fundador, mas de acordo com o interesse público, e pode utilizar meios violentos para concentrar a autoridade necessária para o ato. É assim que Maquiavel justifica o crime inicial que marca a fundação de Roma (a morte de Remo por Rômulo).

Escolhido o território, o foco passam a ser as instituições, e esse é o objeto central de Maquiavel. A escolha das melhores instituições terá como critério principal a conservação da comunidade política fundada. Em outras palavras, deverão ser escolhidas aquelas que melhor contribuírem para a futura manutenção do Estado. A escolha das instituições não se esgota nesse momento fundacional, embora ele seja extremamente importante. Como dito, no exemplo de Roma, elas foram sendo estabelecidas gradualmente. Com isso, Maquiavel, absolutamente inovador, afirma que a manutenção de uma comunidade política não depende apenas do ato de fundação e de sua rememoração ${ }^{9}$, mas de uma constante atualização de seu espírito por meio de novas instituições. Estas devem mudar, conforme a necessidade das circunstâncias. A fundação, portanto, não se trata de um ato acabado, mas deve ser permanentemente atualizada. Daí Leo Strauss e Newton Bignotto (1991, p. 199), nele inspirado, utilizarem a expressão "fundação contínua". Conclui-se, disso, que as instituições não são necessárias somente no momento da fundação de uma república, mas devem ser os mecanismos para a sua própria renovação, necessária para a conservação:

E como estou falando de corpos mistos, como as repúblicas e as seitas, digo que são saudáveis as alterações que as levam de volta a seus princípios. Portanto, são mais bem ordenadas e têm vida mais longa aquelas que, mediante suas ordenações, podem renovar-se muitas vezes, ou que, por algum acontecimento independente de

\footnotetext{
Para uma contextualização da inovação que essa perspectiva de Maquiavel significou para a época, ver Pocock, que afirma ser esta a grande subversão da obra de nosso autor: "O legislador-profeta é uma figura ainda mais rara nos Discorsi do que no Príncipe, porque a virtù do legislador é menos importante do que o processo social e educacional que ele coloca em movimento, então ele pode viver na própria república e ser uma figura menor do que Licurgo ou Moisés. Mas, ao diminuir o papel do legislador, Maquiavel diminuiu sua necessidade da doutrina de Sanvonarola, segundo a qual o estabelecimento da república - a prima forma - deveria ser obra da Graça divina. Se homens não precisam do super-humano para se tornar cidadãos, mas adquirem a cidadania no mundo do tempo e da fortuna, as cidades terrenas e as celestiais acabam por ser novamente idênticas; e isso novamente pode ser tanto uma distinção ética quanto histórica. Nós estamos voltando ao ponto em que foi visto que "estados não são governados por homens santos", e os fins cívicos - incluindo a virtude da cidadania - estão separados dos fins da redenção. Essa é provavelmente a mais subversiva sugestão contida nos Discorsi - e mais que isso, como pode ser bem demonstrado, mais também do que qualquer outra que possamos encontrar em O príncipe" (Pocock, 2003, p. 193-194, tradução minha).
} 
tal ordenação, procedem a tal renovação. E é mais claro que a luz o fato de que, não se renovando, tais corpos não duram (Maquiavel, 2007a, p. 305).

Se somarmos essa ideia de que as instituições são o mecanismo de renovação da república - e, portanto, o tempo todo têm de ser atualizadas -, com a ideia de que elas, numa república que pretende se expandir, devem ser capazes de canalizar as paixões/humores/interesses em conflito, tem-se que em Maquiavel elas assumem um caráter radicalmente contingencial. Aliás, é possível dizer que a criatividade institucional de uma república é a sua $\operatorname{virtù~}^{10}$, ou seja, aquilo que lhe dá condições de lidar com as diversas circunstâncias oferecidas pela fortuna ${ }^{11}$. Outra forma de dizer isso é afirmar que as instituições, na obra de Maquiavel, têm um caráter eminentemente político. Essa é uma característica marcante em sua obra, e talvez aquilo que o coloque num lugar único na história do pensamento político, não somente republicano. O caráter político conferido às instituições por Maquiavel certamente compreende a relação entre lei e liberdade apontada por Skinner como característica do pensamento republicano ${ }^{12}$, e que remonta à distinção

10 "[P]ara Maquiavel, o desenvolvimento da 'virtù' implicava necessariamente a expansão, e que, assim, a incompreensão da imutabilidade do mundo como possibilidade sempre da conquista não está em contradição com suas análises da liberdade, ou mesmo com a criação de grandes impérios"(Bignotto, 1991, p. 210). E a imutabilidade da possibilidade perene de conquista não parece estar em contradição, também, com a contingencialidade da política.

11 Não abordaremos aqui o conceito de virtù de Maquiavel, nem mesmo quando significa atributo de uma cidade. No entanto, julgamos interessante destacar aqui uma passagem de Felix Gilbert, em que fala da virtù como uma espécie de espírito que uma comunidade política possui, que não se confunde com a soma da virtude de seus cidadãos: "O conceito de Maquiavel de 'virtù' postula a existência de coerência entre as instituições da sociedade política. Além disso, em um sentido mais amplo, seu conceito de 'virtù' implica que certos elementos fundamentais de força e vitalidade devem estar presentes em qualquer sociedade bem-organizada, seja qual for sua forma de governo. Algumas formas de governo - na opinião de Maquiavel, era o governo popular - podem ser superior a outras, mas nenhuma poderia funcionar sem virtù. Detalhes da concepção maquiaveliana de virtú podem parecer em desuso ou contraditórios, mas seu conceito é eminentemente frutífero por conter a sugestão de que em cada sociedade bem-organizada um elemento espiritual atravessa todos os seus membros e instituições mantendo-os unidos em um unidade dinâmica que é mais do que a somatória de suas partes constituintes. Ao separar a política dos outros assuntos humanos, Maquiavel deu uma contribuição para a gênese da ideia moderna de estado; seu conceito de virtú representa uma outra" (Gilbert, 1965, p. 180, tradução minha).

12 "A descrição que os autores republicanos dão, no entanto, da relação entre lei e liberdade estão em forte contraste com a descrição que nos é mais familiar, que pode ser encontrada no pensamento político contratualista. Para Hobbes, por exemplo, ou para Locke, a lei preserva nossa liberdade essencialmente por meio de seu poder de coerção sobre outras pessoas. Isto evita sua interferência nos meus direitos reconhecidos, ajuda-me a delimitar em torno de mim mesmo um círculo que os outros não podem trespassar e evita, ao mesmo tempo que eu invada a liberdade dos outros, da mesma forma. Para um teórico como Maquiavel, em contraste, a lei preserva nossa liberdade não meramente por meio de 
entre liberdade positiva e liberdade negativa (Constant, 1985; Berlin, 2002; Skinner, 1986). No entanto, esse caráter político vai além do conteúdo "positivo" da liberdade conferida pela lei, em Maquiavel. Em primeiro lugar, essa permanente atualização que as instituições sofrem e que dá às repúblicas os instrumentos necessários para sua conservação foge à ideia de uma comunidade política ideal, construída no momento de fundação e que reuniria, nesse momento, os elementos necessários para se constituir de forma bem-ordenada e duradoura ${ }^{13}$. Em segundo lugar e, mais importante, ao serem formuladas a partir do conflito, as instituições ganham uma densidade que tornam o seu caráter político e social mais profundo do que simplesmente constituir um conjunto de regras que, se obedecidas, poderão estruturar uma república livre e duradoura. Essa densidade, da maneira como proposta por Maquiavel, não é algo corriqueiro no pensamento político. Vejamos.

Quando Maquiavel fala que as instituições devem resultar do conflito entre os interesses opostos existentes no interior da república, ele está falando, como vimos, de as instituições se constituírem como mecanismo de soluções públicas (Bignotto, 1991) para os problemas enfrentados na vida política da república. Como já apontado, soluções públicas, aqui, devem ser vistas como uma oposição a tudo o que tem como objetivo apenas o atendimento de um interesse particular, seja por meio de privilégios ou por meio de mecanismos não públicos de obtenção dos benefícios de um governo.

$\mathrm{O}$ fato de Maquiavel ter as instituições como mecanismos de soluções públicas para os conflitos não significa dizer que ele seja contra a manifestação dos interesses existentes na comunidade política. Ao contrário, como já sugerimos, e gostaríamos de deixar explícito, a manifestação dos interesses opostos é necessária justamente para que o conflito se torne público e possa ser fonte de instituições adequadas. Um comentador que destacou, além da importância do conflito, a do interesse no pensamento de Maquiavel, de forma incisiva e bastante competente, foi Kent Brudney, que observou

sua coerção sobre os outros, mas também impelindo cada um de nós a agir de um modo particular. A lei também é usada, assim, para forçar-nos a agir for a de nossos padrões habituais ou for a de nosso comportamento auto-interessado, para forçar-nos a cumprir todo o rol de nossos deveres cívicos, e portanto assegurar que o estado livre é ele próprio mantido livre da servidão" (Skinner, 1993, p. 305). Nesse aspecto, ver: "É pela ação presente, pela criação de meios extraordinários, que uma república afronta os ataques do tempo. É da mistura entre a ação criativa e a constituição que nascem os poderes de resistência à corrupção. Maquiavel convida assim os republicanos a exprimir em termos legais o que o tempo os obrigará de qualquer maneira a fazer" (Bignotto, 1991, p. 101). 
que os cidadãos republicanos de Maquiavel não são motivados por noções abstratas de bem comum ou de responsabilidade pública, mas por interesses privados, que ele chama de interesses "de classe" (Brudney, 1984, p. 511) ${ }^{14}$.

A observação de Brudney tem algumas implicações bastante importantes para o entendimento da concepção de república formulada por Maquiavel. A primeira delas é a de que o cidadão maquiaveliano não necessita ser alguém capaz de, a todo tempo, abrir mão de seus interesses em nome de um interesse público. O cidadão da república maquiaveliana é interessado. Isso afasta uma das críticas ao pensamento republicano por ser este muito "exigente" em relação aos cidadãos, na medida em que tem como ponto principal a defesa do interesse público ou do bem comum ${ }^{15}$. A outra consequência, complementar à primeira, é a de que os interesses não são quaisquer deles, mas somente aqueles que têm algum eco coletivo, ou socialmente reconhecido. Em outras palavras, não se trata de qualquer interesse individual, mas daqueles compartilhados por um grupo que tenha identidade "de classe" e que pretenda manifestá-los e submetê-los à discussão, avaliação e disputa publicamente. São esses interesses passíveis de serem canalizados por meio de mecanismos públicos de solução. Segundo Brudney, esses interesses não seriam facciosos, e contribuiriam para uma vida política mais virtuosa e mais bem ordenada (Brudney, 1984, p. 514).

Essa análise de Brudney tem especial importância porque qualifica o interesse presente nos Discursos, permitindo que exploremos melhor a relação entre interesse e conflito na obra de Maquiavel. O próprio Brudney não chega a afirmar isso, mas podemos dizer, a partir de suas observações e daquelas feitas por Georg Simmel sobre o conflito em geral, que o fato de o interesse ter tal qualificação na obra de Maquiavel está relacionado com a valorização do conflito dada pelo autor. Façamos uma breve digressão por Simmel.

\footnotetext{
${ }^{4}$ Nas palavras de Brudney: "À parte as ameaças sofridas por eles de um poder estrangeiro e à parte o apetite de compartilhar a autoridade governamental com a classe oposta, os cidadãos republicanos de Maquiavel não eram frequentemente animados por noções abstratas de responsabilidade e de bem comum. Eles eram mais privatistas (se considerarmos privatistas como compreendendo como aqueles que agem segundo os interesses de classe) e menos públicos (se considerarmos públicos aqueles que agem em comum com todos os cidadãos) do que Shumer pretende nos fazer acreditar" (Brudney, 1984, p. 511, tradução minha). S.M. Shumer é um comentador que lê Maquiavel sob lentes "arendtianas" e é criticado por Brudney.

15 Refiro-me aqui à crítica feita por Habermas em Direito e democracia: entre faticidade e validade, quando o autor formula o seu modelo de democracia, em oposição aos modelos liberal e republicano (Habermas, 2003, p. 10-25).
} 
Em seu artigo "Conflito", Simmel aponta o poder de coesão que o conflito tem sobre a estrutura das partes que se encontram em posição antagônica (Simmel, 1964, especialmente p. 87 e 99). Com isso, embora do ponto de vista da sociedade como um todo o conflito importe em alguma divisão, pois se caracteriza por divergências duais ou antagônicas, ele ao mesmo tempo importa numa unificação no interior de cada uma dessas partes, constituindo um forte elemento de coesão social. Quando cada uma das partes se encontra em conflito, ela tem de se organizar e de deixar claro seu interesse, para que possa, na disputa com a parte antagônica, prevalecer socialmente em relação a ela. Ao organizar cada uma das partes, o conflito acaba por operar uma organização também da própria disputa que se dará publicamente, tornando mais fácil a identificação do que é realmente relevante e está em questão. Tal construção de Simmel, estruturada para a defesa do conflito e de seu caráter coletivista, é feita em oposição à dinâmica da competição, em que se opera uma lógica individualista. Nesse sentido, o conflito, na medida em que é binário, em uma coletividade composta por milhares de membros, sempre fará com que uma pessoa tenha de verificar o que há de comum entre seus interesses e os dos outros, e o que os une e os opõem a outro grupo. A competição, ao contrário, não é binária, e pode ser infinita, atomizando e isolando os indivíduos (Simmel, 1964, p. 71-73), ou os unindo em pequenos grupos para competir melhor contra os demais. Desses pequenos grupos podem emergir justamente os interesses facciosos de que fala Maquiavel.

Ora, quando Brudney afirma que na obra de Maquiavel há uma defesa de que os cidadãos manifestem seus interesses de forma coletiva para que se tenha uma melhor ordem na manifestação pública desses interesses, podemos dizer, inspirados em Simmel, que isso está plenamente de acordo com a valorização do conflito feita por Maquiavel, e reconhecida por muitos comentadores. Em outras palavras, e sem desvalorizar as observações feitas por Brudney, ao contrário, reforçando-as, podemos dizer que, se lermos a valorização do conflito feita por Maquiavel com o olhar sociológico sugerido por Simmel, isso somente poderia importar na defesa da manifestação de interesses coletivos socialmente reconhecidos numa comunidade política.

Com isso, podemos dizer que a interpretação de Brudney sobre a obra de Maquiavel tem o mérito de lançar luz sobre os aspectos mais sociológicos de seu trabalho, efeito este de certa forma pleiteado por McCormick, mas de uma forma menos precisa e mais apropriativa. Talvez o Maquiavel 
de Brudney, assim como o de McCormick, já não seja mais muito fiel ao Maquiavel do século XVI, mas sua leitura certamente abre portas para um tratamento sociológico-político do conflito.

Levando adiante a interpretação de Brudney como nossa e adicionando a ela algumas observações sobre o conflito, podemos dizer que os interesses manifestados pelos cidadãos nos Discursos são interesses coletivos que, na medida em que se opõem, se apresentam em conflito e, com isso, possibilitam uma organização da vida pública. É isso que viabilizará, em nosso entender, o papel das instituições de dar uma solução pública para esses conflitos.

A capacidade de gerar soluções públicas para o conflito de interesses é o que marca a liberdade das repúblicas vocacionadas para a expansão. Nessas repúblicas, sua grandeza está em expandir-se e, ao mesmo tempo, conseguir a liberdade viabilizada pelas suas instituições. Essa liberdade somente se realiza na medida em que as instituições, ou leis, no vocabulário de Maquiavel, conseguem prover as tais soluções públicas de que falamos, demandadas a partir de conflitos de interesses coletivos dentro da comunidade política. $\mathrm{O}$ conflito solucionado publicamente tem um papel integrador da comunidade, tanto do ponto de vista da coesão entre os grupos como do ponto de vista da inclusão do maior número de pessoas possível dentro dos assuntos da república. Este efeito unificador tem papel importantíssimo na realização dos projetos de expansão de uma república.

Maquiavel não explora de forma explícita tais potenciais unificadores, que só viriam a ser reconhecidos pelo pensamento social mais tarde. Mas tudo indica que devamos admitir que sua relação entre conflito e expansão vai além de uma estratégia para aumentar o número de soldados do exército e, assim, incrementar a engrenagem da máquina de guerra que é uma república em expansão, como pretendeu demonstrar Hulliung.

A capacidade de solucionar conflitos de interesses coletivamente organizados e socialmente reconhecidos dá à república uma capacidade de se bem ordenar que lhe confere uma possibilidade de permanência, que por sua vez, também lhe atribui grandeza. Podemos dizer que as leis, na medida em que integram e unificam a comunidade política a partir das soluções por elas viabilizadas, têm um papel central na grandeza de uma república: são elas que possibilitam integração, expansão e permanência. Elas, nessa medida, buscam canalizar as duas paixões presentes em toda república: expandir-se e manter-se livre (Maquiavel, 2007a, p. 95). 
Se somarmos a isso que as leis já cumpriram um papel fundamental na fundação de uma república, temos que, nos Discursos, a vida de uma república e suas leis estão completamente emaranhadas. Essa capacidade de bem ordenar já foi apontada por Maurizio Viroli e citada aqui, mas sem que tenha sido dado destaque ao caráter unificador do conflito.

Com isso, podemos caracterizar melhor o papel das leis na teoria política republicana de Maquiavel. Elas têm um potencial constitutivo evidente e inegável -constituem a república e sua liberdade, mas, mais do que isso, elas têm uma densidade política que, sob a perspectiva de um leitor atual que se encontra sob o pesado legado do liberalismo e de sua concepção de lei - a de que as leis devem apenas limitar as ações dos indivíduos, sendo permitido ao cidadão fazer tudo que as leis não proíbem e, nesta medida, de que a lei é mais uma garantia do cidadão do que algo constitutivo da comunidade política -, talvez seja a marca do pensamento republicano de nosso autor. E essa densidade não se dá apenas pelo fato de serem resultado da contingência e da capacidade dos homens de se adequarem às circunstâncias, como tantas vezes Maquiavel aponta no texto (Maquiavel, 2007a, p. 347-353), mas por serem as leis resultado do conflito de interesses coletivos manifestados publicamente na comunidade política. Lembremos que a densidade vem do conflito e do tipo de interesses que estão em disputa em seu interior. Essa densidade política dada às leis ocupa lugar de distinção no pensamento político anterior e posterior. Assim, se as leis têm, no pensamento político republicano, um papel distinto do proposto pelo liberalismo, como aponta Skinner, Maquiavel vai um pouco além da marca republicana, ao dar às leis um caráter tão dinâmico e denso.

Acabamos de afirmar o potencial constitutivo das leis na formulação republicana de Maquiavel. No entanto, devemos matizar essa afirmação. As leis são formas públicas de solução dos conflitos existentes na república e, nessa medida, fontes da liberdade dessa mesma república, mas não são "em si a origem da liberdade". Elas são fontes da liberdade na medida em que os segmentos em oposição na comunidade política enxergam, nelas, a manifestação de seus "desejos" (Bignotto, 1991, p. 106). Imaginar que as leis, por si sós, garantiriam a constituição da república livre seria retirar do texto de Maquiavel justamente a densidade social de que falamos anteriormente. Seria imaginar, também, que a república bem ordenada poderia surgir a partir da elaboração inteligente e acurada de alguns sensíveis, ou, sendo 
mais exigente, extraordinários, legisladores. Não. Ainda que a grandeza proposta por Maquiavel seja algo extraordinário, porque não são todas as repúblicas que conseguem se adequar às contingências do tempo e suportar todas as ocasiões que se tornam fontes de corrupção, a grandeza se origina da vida cotidiana e social da cidade, pois ela é, como tudo em Maquiavel, contingencial e política. E a liberdade é um problema de todas as formas de governo, uma vez que ela nasce do desejo do povo de não ser oprimido (Bignotto, 1991, p. 118) ${ }^{16}$.

Se é verdade que a liberdade é um problema de todas as formas de governo, na obra de Maquiavel, é verdade também que, para nosso autor, é nas repúblicas que ela pode se realizar, na medida em que encontra nas instituições não só mecanismos de evitar as causas de corrupção mas também vias de canalização dos interesses opostos existentes na comunidade política, principalmente os do povo.

Com isso, vemos que é justamente a densidade que as leis têm na obra de Maquiavel que impede que elas sejam os únicos elementos constitutivos da comunidade política e de sua liberdade. São os elementos essenciais na fundação de qualquer república, mas a grandeza e a liberdade desta dependerá da própria grandeza dos conflitos sociais que, expressos e canalizados nas leis, podem dar vida livre e duradoura à república.

Enfim, na república maquiaveliana, as leis são o mecanismo de expressão e extravasamento dos conflitos de interesses. O conflito de interesses nos Discursos de Maquiavel é o nosso objeto neste texto. Definamos agora mais precisamente de que se trata.

\section{O conflito de interesses republicano de Maquiavel}

Ao longo deste texto, tentamos delimitar e qualificar o que seria o conflito de interesses nos Discursos de Maquiavel. Vimos que não se tratava de qualquer oposição de interesses, mas sim daquela em que os interesses são passíveis de serem canalizados em mecanismos públicos de solução. Nesse sentido, tais interesses deveriam ter uma pretensão de se tornarem comuns e transparentes e, assim, não serem facciosos, nem secretos. Utilizamos as observações de Brudney para indicar que os conflitos defendidos por Ma-

16 Embora essa passagem esteja incluída em um capítulo sobre a liberdade em O príncipe, julgamos que ela se aplica perfeitamente aos Discursos, e parece que o próprio Bignotto pretendia, com ela, dar uma interpretação geral à obra de Maquiavel. 
quiavel são coletivos, ainda que ele não os tenha qualificado nesses termos. Mas talvez ainda seja necessário deixar um pouco mais claro de que realmente trata esse conflito de interesses maquiaveliano. Para isso, nas próximas seções não diremos nada novo, apenas, a partir do que já foi argumentado anteriormente, sugeriremos que a definição de conflito de interesses está ancorada em algumas dicotomias que nos ajudarão. São elas: privado/público; particular/comum; facção/coletividade. Vejamos como cada uma delas se relaciona com nosso conflito de interesses.

\section{A publicidade do conflito de interesses}

Se a corrupção é um dos opostos da liberdade, e esta é um atributo da república como um todo, por outro lado, as fontes de corrupção indicadas por Maquiavel sempre se constituem a partir de expedientes privados de manifestação de interesses. Destaque é dado em sua obra para as calúnias, às quais nosso autor opõe as denúncias públicas. Mas poderíamos dizer que as calúnias também se dão publicamente. Aliás, se seus efeitos não forem públicos, não se constituem como tal. Ocorre que, como Maquiavel bem ressalta, as calúnias não são submetidas a contraprovas e não utilizam expedientes transparentes e públicos - no sentido de serem acessíveis a todos - para se manifestarem. Seu resultado - a atribuição de algo pernicioso a alguém, é público, mas o ato que a provoca é privado e, na maioria das vezes, nem se sabe quem é seu autor. Por isso as denúncias públicas são mecanismos apropriados de canalização da paixão popular: por meio delas, os denunciados podem, publicamente, defender-se e todos sabem a autoria e a motivação da denúncia.

Tal mecanismo de denúncias públicas não é suficiente para a canalização de todas as paixões existentes numa república, nem mesmo se constitui no melhor mecanismo de solução pública de conflitos. Como visto, o povo maquiaveliano deseja não ser oprimido e com esse objetivo leis e instituições como os Tribunatos da plebe devem vir a público. Na estrutura institucional descrita por Maquiavel como desejável para uma república, não basta o poder de denunciar, mas é necessário também o poder de propor e de vetar (McCormick, 2011). E tudo isso deve ocorrer publicamente.

Ou seja, na proposta maquiaveliana, os segmentos que detêm os interesses opostos têm de ser identificados e, a partir do embate que se dá politicamente, a solução institucional, que por sua vez também é pública, poderá 
ser encaminhada. Pode-se dizer, ao contrário, que interesses manifestados secretamente ou ardilosamente não estão aptos a se submeterem aos mecanismos institucionais de solução e são, portanto, possíveis fontes de corrupção da república. Os interesses em conflito que constituirão a fonte da liberdade por meio das instituições são transparentes e públicos.

\section{O conflito de interesses que se pretendem comuns}

Uma das principais preocupações de Maquiavel na sua formulação republicana é a formação, no interior da comunidade política, de um terreno comum, que propicie a boa ordem e a unidade necessárias para a grandeza da república, inclusive em seus projetos de expansão. Daí a importância que dá à religião e à educação, no capítulo 2, do Livro II, que trata justamente da expansão da república. Esse terreno comum é o que possibilita o compartilhamento de valores, principalmente, o valor da pátria e da liberdade, necessários para que os cidadãos defendam e preservem a república.

Outra faceta desse terreno comum defendido por Maquiavel é a sua condenação a quaisquer manifestações de interesses particulares no interior da república. Nesse sentido, mais um ponto do conflito de interesses maquiaveliano, fonte de instituições duradouras e garantidor da liberdade é que ele nunca se encerra no terreno do particular, mas sempre se destina ao comum. Tentemos dizer isso mais claramente.

Os interesses conflitantes vocacionados a serem alvos de soluções institucionais não são nunca aqueles de pequenos grupos, que pretendam, de alguma forma, obter algum tipo de distinção ou privilégio. Ao contrário, os interesses passíveis de serem expressos institucionalmente são aqueles que, ainda que sejam defendidos por um grupo - e isso sempre ocorre, porque os interesses são sempre parciais, tenham a pretensão de se tornarem interesse de toda comunidade. Apenas para dar um exemplo, não teria cabimento que um dos segmentos (povo ou aristocracia), interessado em obter benefícios na nomeação de determinados cargos públicos, pretendesse ver o seu desejo atendido por meio das instituições. Essa pretensão não tem vocação de se tornar comum, pois ela é, em sua essência, particularista, na medida em que visa o privilégio de uma parte dos cidadãos sobre os demais.

Com isso, temos a dizer que o conflito de que fala Maquiavel é de interesses parciais, sim, mas que se pretendem comuns, e não almejam privilégios ou benefícios que resultem no prevalecimento de um segmento sobre os demais. 


\section{O conflito de interesses coletivos}

A última dicotomia facção/coletividade tem estreita relação com a anterior, mas merece uma análise em separado. Podemos dizer que o conflito de interesses defendido por Maquiavel é o de interesses não coletivos. Quando dizemos coletivo, nesse caso, não estamos querendo dizer não individual, como seria intuitivo supor, mas não faccioso. Façamos a distinção.

Interesse faccioso é todo aquele que, individual ou não, tem índole facciosa, ou seja, a de produzir na comunidade política uma separação ou cisão. Nesse sentido é que Maquiavel afirma que "os partidos criam as facções que dividem as cidades, e originam a ruína dos Estados" (Maquiavel, 2007a, p. 34). Como se vê, o partido é uma coletividade, mas produz facções. Quando, então, se tem uma coletividade que não produz facções?

Brudney, em sua análise já citada aqui, fala de interesses "de classe". Tais interesses, os do povo e os dos aristocratas, apresentam coesão interna nesses grupos - o que ocasiona o conflito - e, mais do que isso, têm uma identidade reconhecida publicamente e uma vocação de se tornarem comuns, e não são apenas particulares, como distinguimos no item anterior. Assim, os interesses facciosos são sempre particulares, embora não sejam individuais, enquanto os não facciosos, que estamos chamando aqui de coletivos, se pretendem sempre comuns.

Com isso, pode-se questionar se é necessária essa última distinção entre interesse faccioso e coletivo, tendo em vista a distinção feita entre interesse comum e particular. Julgamos ser necessária para deixar claro que não é suficiente que os interesses, para integrarem o conflito tal como defendido por Maquiavel, sejam não individuais. Interesses não individuais podem ser facciosos e, nessa medida, particulares, como qualquer outro interesse individual.

O conflito de interesses de que fala Maquiavel é, portanto, aquele que se dá a partir de interesses coletivos e comuns, passíveis de serem expressos por meio de mecanismos institucionais públicos e transparentes e que, nessa medida, se tornam elemento constitutivo da liberdade da república.

Maquiavel, em sua dedicatória nos Discursos, anuncia que tratará das coisas do mundo. Os interesses certamente são coisas do mundo, mas aqueles que interessam à república livre e bem-ordenada de Maquiavel são aqueles vocacionados para se manifestarem no mundo e dignos de permanecer nele - ao menos por um breve tempo - por meio de sua expressão nas institui- 
ções. São esses interesses que configurarão o conflito capaz de promover a grandeza da república livre em expansão.

\section{Conclusão}

O objetivo deste texto foi colocar os Discursos de Maquiavel em um lugar distintivo na teoria política a partir da explicitação da forma como o conflito de interesses foi por ele tratado. Conforme o debate exposto e a posição nele assumida, procurou-se extrair as consequências da densidade conflitiva presente em sua teoria.

Espera-se, com isso, reservar o lugar de Maquiavel, especialmente o republicano, como autor ainda fecundo não somente para o conhecimento da história das ideias políticas mas para a teoria política atual, tal como a exposição do debate recente sobre a obra do autor demonstrou.

\section{Referências}

ADVERSE, Helton (2009). Maquiavel: política e retórica. Belo Horizonte: Editora UFMG.

ARENDT, Hannah (1965). From Machiavelli to Marx. Disponível em: http:// memory.loc.gov/mss/mharendt_pub/04/040380/0001d.gif. Acessado em 7 mai. 2002.

BERGSTRÖM, Lars (1970). "What is a conflict of interest?". Journal of Peace Research, v. 7, n. 3, p. 197-217.

BERLIN, Isaiah (2002). "Dois conceitos de liberdade", em Estudos sobre a humanidade. São Paulo: Companhia das Letras.

BIGNOTTO, Newton (1991). Maquiavel republicano. São Paulo: Loyola.

BONADEO, Alfredo (1973). Corruption, conflict and power in the works and times of Niccolo Machiavelli. Berkeley: University of California Press.

BRUDNEY, Kent M. (1984). "Machiavelli on social class and class conflict". Political Theory, v. 12, n. 4, p. 507-519.

CONSTANT, Benjamin (1985). "A liberdade dos antigos comparada à liberdade dos modernos". Revista Filosofia Política, n. 2. Porto Alegre: L\&PM.

GILBERT, Felix (1953). “The composition and the structure of Machiavelli's Discorsi". Journal of the History of Ideas, v. 14, n. 1, p. 136-156.

(1965). Machiavelli and Guicciardini: politics and history in sixteenth-century Florence. Princeton: Princeton University Press. 
HABERMAS, Jürgen (2003). Direito e democracia: entre facticidade e validade. Rio de Janeiro: Tempo Brasileiro.

HIRSCHMAN, Albert (1978). Las pasiones y los intereses. México: Fondo de Cultura Económica.

HÖRNQUIST, Mikael (2004). Machiavelli and empire. Cambridge: Cambridge University Press.

HULLIUNG, Mark (1983). Citizen Machiavelli. Princeton: Princeton University Press.

MACHIAVELLI, Niccolò (2000). Discorsi sopra la prima deca di Tito Livio. Milão: Rizzoli.

MANSFIELD, Harvey C. (2001). Machiavelli's new modes and orders: a study of the Discourses on Livy. Chicago: The University of Chicago Press. MAQUIAVEL, Nicolau (1987). O príncipe. Coleção Os Pensadores. São Paulo: Nova Cultural.

(2007a). Discursos sobre a primeira década de Tito Lívio. São Paulo: Martins Fontes.

(2007b). História de Florença. São Paulo: Martins Fontes.

MCCORMICK, John P. (2001). "Machiavellian democracy: controlling elites with ferocious populism”. The American Political Science Review, v. 95, n. 2, p. 297-313.

(2003). "Machiavelli against republicanism: on the Cambridge School's 'Guicciardinian moments'”. Political Theory, v. 31, n. 5, p. 615643.

(2011). Machiavellian democracy. Cambridge: Cambridge University Press.

MÉNISSER, Thierry (2012). Vocabulário de Maquiavel. São Paulo: Martins Fontes.

POCOCK, John G. A. (1985). "Machiavelli in the liberal cosmos". Politicial Theory, v. 13, n. 4, p. 559-574

(2003). Machiavellian moment. Princeton: Princeton University Press.

SIMMEL, Georg (1964). Conflict and the web of group-affiliations. New York: Free Press.

SKINNER, Quentin (1986). "The paradoxes of political liberty", em SEN, Amartya et al. (eds.). The Tanner lectures on human values. Salt Lake City: University of Utah Press. 
(1988). Maquiavel. São Paulo: Brasiliense.

(1999). "The republican ideal of political liberty", em BOCK, Gisela; SKINNER, Quentin \& VIROLI, Maurizio (eds.). Machiaveli and republicanism. Cambridge: Cambridge University Press.

VIROLI, Maurizio (1998). Machiavelli. Oxford: Oxford University Press.

\section{Resumo:}

O caráter positivo da conflitividade na república nos Discorsi de Maquiavel já é algo bastante reconhecido nos debates acadêmico internacional e nacional. $O$ objetivo deste artigo é explorar como o conflito de interesses é tratado nessa obra e qual seu alcance. Para esse fim, serão debatidas as concepções de liberdade e de grandeza presentes no mesmo livro. A partir desse debate, o conflito maquiaveliano será caracterizado como aquele formado por interesses coletivos e comuns, passíveis de serem expressos por meio de mecanismos institucionais públicos e transparentes e que, nessa medida, se torna elemento constitutivo da liberdade da república. Tal caracterização, sem dúvida, dá à obra do autor uma atualidade bastante fecunda.

Palavras-chave: conflito, interesse, Maquiavel, república, grandeza.

\section{Abstract:}

The positive character of the conflict in the republic in Machiavelli's Discorsi is well known in international and national academic debates. The aim of this paper is to explore how conflict of interests is approached in that work as well as its scope. In order to do this, conceptions of liberty and greatness are also explored. From that debate, Machiavellian conflict is characterized as composed by collective and common interests, which can be expressed by public and transparent institutional devices. Therefore, it becomes a constitutive part of republican freedom. Such interpretation certainly gives his work a very fruitful timeliness.

Keywords: conflict, interest, Machiavelli, republic, greatness.

Recebido em $1^{\circ}$ de junho de 2013.

Aprovado em 30 de agosto de 2013. 